\title{
Besatzung, Kollaboration, Holocaust. Neue Studien zur Verfolgung und Ermordung der europäischen Juden [Okupacja, kolaboracja, Holokaust. Nowe studia na temat prześladowań i wymordowania Żydów europejskich], red. Johannes Hürter, Jürgen Zaruski, München 2008 (Schriftenreihe der Viertelsjahrhefte für Zeitgeschichte, t. 97), s. 210
}

Na ten tom złożyło się osiem studiów oraz dodany w charakterze swoistego aneksu reportaż Wasilija Grossmana „Ukraina bez Żydów”. Ich wspólnym tematem jest sytuacja w krajach okupowanych przez III Rzeszę w kontekście niemieckiej polityki antyżydowskiej, a główny wątek stanowi problem postaw i działań społeczeństw okupowanych wobec Żydów. Pomysł zgromadzenia tych tekstów w osobnym wydawnictwie zrodził się spontanicznie, gdy do redakcji „Viertelsjahrhefte für Zeitgeschichte” zaczęły trafiać kolejne artykuły o zbliżonej tematyce.

Tom otwiera praca Hätte der Holocaust beinahe nicht stattgefunden? [Czy Holokaust mógł się nie zdarzyć?] pióra historyka i geografa Pawła Poljana z Rosyjskiej Akademii Nauk na temat listu Jewgienija Czekmieniewa do Wiaczesława Mołotowa z 9 lutego 1940 r. Ówczesny szef i przewodniczący kolegium komitetu ds. przesiedleń informował o propozycji, którą otrzymał z Wiednia i Berlina, by przesiedlić do ZSRR wszystkich Żydów przebywających w III Rzeszy i terenach przez nią kontrolowanych, i sugerował jednocześnie, by ten pomysł odrzucić. Analizowany przez Poljana dokument znany jest wprawdzie od kilkunastu lat i doczekał się nawet publikacji drukiem w książce Gennadija Kostyrczenki Tajna politika Stalina. Wlast' $i$ antisemitizm [Tajna polityka Stalina. Władza i antysemityzm] (2001), nie został jednak należycie wykorzystany przez badaczy Zagłady. Zdaniem rosyjskiego historyka niesłusznie, ponieważ dotyczy on nieznanego dotychczas nazistowskiego projektu deportacji Żydów. Tym bardziej, że autorami tego planu - jak ustalił Poljan - musieli być Franz Josef Huber oraz Adolf Eichmann, ówcześni kierownicy „biur ds. przesiedleń” w Wiedniu i Berlinie. Opierając się na tym dokumencie, Poljan dowodzi, że Niemcy, obok dobrze udokumentowanych i znanych historykom projektów Nisko i Madagaskar, rozważali krótko na przełomie 1939 i 1940 r. również pomysł deportowania wszystkich „swoich” Żydów do ZSRR. Jednak pomysł „naiwnych Niemców”, używając słów rosyjskiego historyka, był z góry skazany na niepowodzenie. Abstrahując od innych przeszkód, Stalin, jak utrzymuje Poljan, nigdy nie zgodziłby się na przyjęcie w granice państwa sowieckiego ponad 2 milionów „obcych ideowo” ludzi.

Kolejne artykuły poświęcone są przykładom współdziałania z Niemcami na różnych etapach polityki antyżydowskiej. Christoph Kreutzmüller z Uniwersytetu Humboldta w Berlinie w artykule Die Erfassung der Juden im Reichskommissariat der besetzten niederländischen Gebiete [Ewidencja Żydów w Komisariacie Rzeszy 
na holenderskich terenach okupowanych] analizuje sytuację w Holandii i dowodzi, że tamtejszy nowoczesny system ewidencji ludności oraz gotowość do współpracy ze strony urzędników i statystyków holenderskich w wielkim stopniu przyczyniły się do tragedii holenderskich Żydów. Pragnąc - jak twierdzili - uniknąć „większego zła”, Holendrzy zestawili według niemieckich wytycznych listy osób odpowiadających nazistowskiej kategorii „Żyda”, ułatwiając tym niemal całkowitą ich eksterminacje. Kreutzmüller wykazuje również, że zakres współpracy z okupantem miał dużo szerszy zasięg, niż dotychczas przyjmowano, i nie ograniczał się do wąskiego kręgu najbliższych współpracowników Jakobusa Lambertusa Lentza, twórcy holenderskiego systemu ewidencji ludności. W prace nad rejestrem „osób krwi żydowskiej” zaangażowany był bowiem cały pion urzędów meldunkowych, aż do najniższych jego szczebli.

Na Litwie, której poświęcone jest studium Joachima Taubera Die litauische Verwaltung und die Juden in Vilnius 1941-1943 [Administracja litewska a Żydzi w Wilnie 1941-1943], nie stosowano wprawdzie nowoczesnych technik statystycznych, ale i tam Niemcy w prześladowaniu Żydów otrzymali silne wsparcie ze strony administracji publicznej, wskutek czego zakres żydowskich strat osobowych był w ujęciu procentowym porównywalny z Holandią. Już w pierwszych tygodniach po wkroczeniu Wehrmachtu jednostki policji litewskiej podporządkowane Einsatzkommando 9 Einsatzgruppe A otrzymały polecenie sporządzenia imiennych list wileńskich Żydów, w pierwszym rzędzie inteligentów, działaczy politycznych i innych prominentów. Spisy te posłużyły następnie za podstawę do rewizji, aresztowań i egzekucji. W tym samym czasie administracja Wilna opracowała samodzielnie (Niemcy mieli zbyt słabe rozeznanie panujących w mieście warunków) listę bogatych Żydów, która stała się punktem wyjścia zorganizowanego rabunku. Litwini i Niemcy współpracowali w zakresie organizacji wileńskiego getta, następnie eksploatacji gospodarczej i - na koniec - eksterminacji jego mieszkańców. Litewska administracja miasta, choć oczywiście w żadnym razie nie była instancją decyzyjną, nie ograniczała się jedynie do realizacji niemieckich wytycznych, ale w kilku znanych wypadkach wykazywała się własną inicjatywą, jak choćby próba wymuszenia na wyniszczanej społeczności żydowskiej zaległych rzekomo świadczeń podatkowych. Znamienne, że w zarządzie miasta Wilna funkcjonował lokalny odpowiednik niemieckiego referenta ds. żydowskich, pośredniczący w kontaktach administracji okupacyjnej z Radą Żydowską. Równie ścisłe więzi łączyły niemiecki i litewski aparat represji. Policjanci litewscy sporządzali listy proskrypcyjne, na podstawie których dokonywali aresztowań, by następnie przekazać pochwyconych niemieckiej policji bezpieczeństwa. Obok policji szczególną rolę odegrały miejscowe bataliony policji pomocniczej, które nadzorowały organizację getta w Wilnie i jego późniejszą likwidację, transportowały ofiary na miejsce straceń w Ponarach czy też wykonywały służbę wartowniczą w miejscach pracy czy izolacji. Znaczący udział w tragedii wileńskich Żydów mieli również członkowie 130-osobowej litewskiej policji bezpieczeństwa. Formacja ta nie tylko prowadziła przesłuchania Żydów, ale często niezależnie od Niemców rozstrzygała o ich życiu lub śmierci. 
Nie może więc dziwić, że w pamięci żydowskich ocalałych, jak zauważa Tauber, Litwini zajęli szczególne miejsce jako bezpośredni współsprawcy ich tragedii. Nie zmienia to faktu - co Tauber szczególnie podkreśla - że do wymordowania dziesiątków tysięcy ludzi nigdy by nie doszło bez rasistowsko-antysemickiej ideologii narodowego socjalizmu i jego niemieckich sprawców, bez ich inicjatywy, planowania i realizacji.

Równie dramatyczny przebieg miały wydarzenia na Węgrzech, a zaangażowanie lokalnych władz i ludności było nawet jeszcze większe. O sytuacji na Węgrzech traktują dwa artykuły: Franza Sz. Horváta Volkstumspolitik, soziale Kompensation und wirtschaftliche Wiedergutmachung. Der Holocaust in Nordsiebenbürgen [Polityka narodowościowa, kompensacja społeczna i gospodarcze zadośćuczynienie. Holokaust w północnym Siedmiogrodzie] oraz Die Schlacht um den Balkan und der Holocaust in Ungarn: Krieg, Rettungsbemühungen und das Überleben des Budapester Ghettos [Bitwa o Bałkany i Holokaust na Węgrzech: wojna, próby ratowania i ocalenie budapeszteńskiego getta] pióra Shlomo Aronsona z Uniwersytetu Hebrajskiego w Jerozolimie. Pierwszy z nich szkicuje położenie ludności żydowskiej we włączonym do Węgier w 1940 r. północnym Siedmiogrodzie. Chociaż główna fala deportacji i eksterminacji przypadła tam na schyłkowy okres wojny, spośród 130 tys. tamtejszych Żydów Holokaust przeżyło zaledwie 10 do 35 tys. Rekonstruując kontekst ideologiczny i analizując motywy władz, Horvát tłumaczy specyfikę Zagłady Żydów węgierskich. Autor podkreśla bezdyskusyjną gotowość Węgrów do współpracy w gettoizacji i grabieży żydowskich współobywateli. Jedno ze źródeł nastrojów antyżydowskich upatruje paradoksalnie w polityce rumunizacji prowadzonej przez Bukareszt. Usuwanie Węgrów z eksponowanych stanowisk rodziło ich frustrację, która znajdowała ujście w nastrojach antysemickich. Kryzys gospodarczy jeszcze je spotęgował. Wbrew nadziejom na cud gospodarczy, którego spodziewano się pod rządami Budapesztu, borykano się w Siedmiogrodzie z narastającymi problemami ekonomicznymi. Remedium na trapiące region trudności upatrywano w „odzyskaniu kontroli nad gospodarką”, którą rzekomo zawładnęli Żydzi, oraz w przywróceniu równowagi demograficznej na korzyść etnicznych Węgrów. Stąd wziął się właśnie, zdaniem Horváta, aplauz węgierskiej elity dla koncepcji przesiedleń: usunięcia zajmujących „węgierską” ziemię Żydów i zastappienia ich etnicznymi Węgrami.

W drugim z artykułów poświęconych wydarzeniom na Węgrzech poddano analizie dramatyczną rozgrywkę z przełomu 1943 i 1944 r., której stawką było życie budapeszteńskich Żydów. Zdaniem Aronsona zawdzięczali oni ocalenie nie, jak dotychczas przyjmowano, inicjatywie Raoula Wallenberga czy Rezső Kasztnera, lecz decyzji niemieckiego komendanta Budapesztu i generała Waffen-SS Karla Pfeffera-Wildenbrucha, który - zapewne z powodów militarnych - chronił miejscowych Żydów przed bandami węgierskich strzałokrzyżowców.

Znaczenie lokalnych organów dla przygotowania deportacji widoczne jest najlepiej na tle krajów, w których gotowość do współpracy była dużo mniejsza. Takim przykładem może być sytuacja w Belgii, której Insa Meinen poświęciła artykuł Die 
Deportationen der Juden aus Belgien und das Devisenschutzkommando [Deportacje Żydów z Belgii i oddział ds. zabezpieczania dewiz]. W świetle tej analizy już pierwsze posunięcia antyżydowskie nie znalazły aprobaty wśród belgijskiej ludności, a zamysł wykorzystania lokalnej policji do realizacji polityki nazistowskiej napotykał opór. Belgijscy policjanci i urzędnicy niechętnie widzieli siebie w roli prześladowców, a Bruksela stała się wręcz, jak uważa Meinen, „bastionem przeciw aresztowaniom kobiet, mężczyzn i dzieci”, którzy tylko dlatego dostali się na celownik niemieckiego aparatu represji, że uchodzili w jego oczach za Żydów. Z tego właśnie względu nie powiodła się próba wykorzystania w lipcu 1942 r. brukselskiej policji do szeroko zakrojonych łapanek. We września 1942 r. burmistrz Brukseli, będący zwierzchnikiem policji komunalnej, odrzucił żądania udziału podległych mu formacji w wielkiej łapance zagranicznych Żydów, którzy mieli zapełnić wagony przeznaczone do Auschwitz. Nie inaczej było w Antwerpii, gdzie udało się wykazać zaledwie dwadzieścia przypadków aresztowania pojedynczych Żydów przez funkcjonariuszy belgijskich. Nie oznacza to oczywiście, że takich przypadków nie było więcej, jednak pozwala wykluczyć masowy udział belgijskich formacji policyjnych w prześladowaniach Żydów. Niemcy, chociaż zawsze mogli liczyć na lokalnych kolaborantów, usłużnych donosicieli czy niekiedy nawet samych Żydów zmuszanych do wskazywania na ulicach pobratymców, musieli tym razem samodzielnie wypełnić stawiane im przez zwierzchników zadania. Nad ich realizację pracowały ręka w rękę wszystkie komórki aparatu okupacyjnego, łącznie z mało znanym i zbadanym tytułowym oddziałem ds. zabezpieczania dewiz (DSK), któremu Meinen poświęca więcej miejsca. Ta licząca kilkadziesiąt osób formacja, formalnie zajmująca się przestępstwami natury dewizowej, brała bezpośredni udział w wyłapywaniu Żydów, przekazywanych następnie organom policji bezpieczeństwa.

Z punktu widzenia czytelnika polskiego szczególnie interesująca jest praca Stephena Lehnstaedta (obecnie pracownika naukowego Niemieckiego Instytutu Historycznego) Alltägliche Gewalt. Die deutschen Besatzer in Warschau und die Ermordung der jüdischen Bevölkerung [Codzienna przemoc. Niemieccy okupanci w Warszawie i wymordowanie ludności żydowskiej]. Na podstawie zapisów współczesnych (np. listów i dzienników) i powojennych relacji przebywających w tym mieście Niemców, kobiet i mężczyzn, wnioskuje, że byli oni świadomi codziennej przemocy wobec Żydów. Urzędnicy aparatu okupacyjnego widzieli ją w trakcie wizyt w getcie warszawskim, które mimo oficjalnych zakazów było często odwiedzane, nie tylko w celach służbowych. Byli świadomi głodu, chorób wyniszczających jego mieszkańców, masowej śmiertelności i wreszcie dokonujących się tam egzekucji, nazywanych często „odstrzeliwaniem”. Od pewnego momentu powszechna stała się wśród nich świadomość celów i skutków polityki Niemiec wobec Żydów. Większość obserwatorów przywykła do traktowania przemocy w kategoriach koniecznej na ziemiach okupowanych polityki państwowej, której zasadności nie kwestionowano. Postępujący proces adaptacji i akceptacji posunął się tak daleko, że płonąca dzielnica żydowska stała się swoistym spektaklem rozbijającym nudę 
codzienności. Postawy takie jak znanego polskiemu czytelnikowi Wilma Hosenfelda1 należały do zdecydowanej mniejszości.

Ostatni z zamieszczonych w tomie artykuł - Neue Ergebnisse zur Geschichte des Holocaust in der Ukraine. Das „Oral History” - Projekt von Yahad-In Unum und seine wissenschaftliche Bewertung [Nowe ustalenia na temat dziejów Holokaustu na Ukrainie. Projekt „oral history” Yahad-In Unum i ocena jego wartości naukowej] Patricka Desbois i Eduarda Hussona - tematem i formułą różni się od pozostałych tekstów. W zasadzie nie jest analizą naukową, a sprawozdaniem z realizacji projektu, w ramach którego przepytano około tysiąca nieżydowskich Ukraińców na temat mordów popełnionych w ich okolicy na Żydach. Indagowani byli naocznymi świadkami tych mordów, albo jako bierni obserwatorzy, albo jako aktywni pomocnicy. Stanowili tym samym część miejscowej ludności lokującą się w trudnej do zdefiniowania szarej strefie pomiędzy sprawcami a ofiarami. Na przykładzie miasteczka Busk autorzy starają się wykazać wartość przekazów ustnych dla rekonstrukcji wydarzeń, codzienności czasu Zagłady i oczywiście lokalizacji miejsc masowych mordów, zastrzegając przy tym konieczność konfrontacji tych materiałów z innymi przekazami źródłowymi.

Tom zamyka reportaż Wasilija Grossmana, który w rodzinne strony na Ukrainie wrócił jesienią 1943 r., w charakterze korespondenta wojennego, podążając szlakiem bojowym Armii Czerwonej. Wprawdzie już wcześniej z sowieckich terenów okupowanych przez Niemcy docierały informacje o dokonującej się tam eksterminacji ludności cywilnej, lecz dopiero naoczna konfrontacja odsłoniła przed Grossmanem ogrom zbrodni. Autor zastał Ukrainę bez Żydów i tak też zatytułował swój reportaż. Jego tekst nie tylko ilustruje recepcję Holokaustu, ale dowodzi również, że Grossman jako jeden z pierwszych zrozumiał wyjątkowość Zagłady Żydów. Mimo to „Ukraina bez Żydów” nie znalazła się wśród kanonicznych tekstów poświęconych Zagładzie i za sprawą meandrów sowieckiej polityki wobec Żydów ich wyjątkowy los został zaliczony do ogólnej kategorii prześladowań obywateli sowieckich, sam zaś artykuł mógł ukazać się jedynie w jidysz, tracąc tym szansę na szerszy rezonans.

Besatzung, Kollaboration, Holocaust jest więc zbiorem studiów traktujących o wybranych przypadkach różnych form współpracy - lub jej braku - w prześladowaniu Żydów, dlatego nie jest i nie stara się być wyczerpującą analizą zagadnienia. Stanowi niewątpliwie ważny krok ku lepszemu poznaniu stosunku ludności krajów okupowanych przez III Rzeszę do zagłady Żydów. Szczegółowe omówienie każdego tekstu z osobna przekraczałoby ramy tej recenzji. Można oczekiwać, że na bardziej dogłębną ocenę analizowanych zjawisk złożą się różnego rodzaju źródła, w tym świadectwa żydowskich ofiar i kolaborantów. Doskonale widać to w pracy Franza Horváta, a zabrakło tego w tekście Lehnstaedta i - w mniejszym stopniu -

${ }^{1}$ Jego dzienniki i listy zostały opublikowane w języku polskim (W. Hosenfeld, „Staram się ratować każdego". Życie niemieckiego oficera w listach i dziennikach, przeł. J. Tycner et al., Warszawa 2007). 
Taubera. Wydaje się również, że w sprawozdaniu Desbois i Hussona zbyt pochopnie zaliczono ukraińskich chłopów do aktywnych uczestników zdarzeń. Można domniemywać, że przynajmniej część z nich nie kopała Żydom grobów dobrowolnie i nie z własnej inicjatywy transportowała ich na miejsca egzekucji, chociaż bez wątpienia nie brakowało i takich, którzy przyczynili się do tragedii Żydów. Zastrzeżenia budzi nadmierne zaufanie tych autorów do relacji składanych dziesiątki lat po zdarzeniach. Historycy nigdy nie lekceważyli ustnych przekazów świadków zdarzeń, pamiętając jednak o znaczeniu upływu czasu dla ludzkiej pamięci. Zabrakło osobnego artykułu lub choćby passusu poświęconego analizie porównawczej realiów okupacyjnych na Wschodzie i Zachodzie. Pisząc o dobrowolnej współpracy, należy pamiętać, że zakres możliwości odmowy współpracy w Belgii i na Ukrainie był zdecydowanie różny, jak również możliwe takiej odmowy konsekwencje.

Nie zmienia to faktu, że publikacja pod redakcją monachijskich historyków jest nowym, interesującym spojrzeniem na Holokaust, bo jak powiedziano, w centrum badań stawia nie sprawców, o których tyle już napisano, ale ich pomocników. Jest też lekturą trudną, bo przedstawia wkład w Holokaust ludzi niekiedy przypadkowych, niekoniecznie powodowanych światopoglądem czy ideologią nazistowską. Każe zastanowić się nad stwierdzeniem Zygmunta Baumana, przywołanym przez Jacka Leociaka w jego książce Tekst wobec Zagłady: „Najbardziej przerażającą informacją wniesioną przez Holocaust [...] jest nie przypuszczenie, że »to« mogłoby się przydarzyć również nam, ale że również my moglibyśmy tego dokonać”.

Wojciech Lenarczyk 